\title{
Container Production of Pawpaw Seedlings
}

\author{
Kirk W. Pomper, ${ }^{1}$ Desmond R. Layne, ${ }^{2}$ and Snake C. Jones ${ }^{3}$
}

AdDITIONAL INDEX wORDS. Asimina triloba, bottom heat, chlorophyll, root : shoot ratio, kentucky banana, fertilizer regime, shading, biomass, propagation

Summary. Pawpaw (Asimina triloba) is a native North American tree that has potential as a new fruit crop or for use in landscapes, but until recently, little information has been available to nurseries on containerized production of this species. Pawpaw seedlings develop a strong taproot with a fragile root system, which can be easily damaged upon digging; therefore, most nurseries propagate trees in containers. Pawpaw seed requires stratification for optimal germination and seed is sensitive to desiccation. The seed also cannot tolerate freezing temperatures $\left[<-15^{\circ} \mathrm{C}\left(5.0^{\circ} \mathrm{F}\right)\right]$. A well-aerated potting substrate with a high sphagnum peat moss component ( $>75 \%$ by volume), cation exchange capacity, and water holding capacity can be used effectively in container production. Tall containers should be used to accommodate the developing taproot of seedlings. The slow-release fertilizer Osmocote 14-14-14 (14N-6.1P-11.6K) incorporated into Pro-Mix BX potting substrate can be used effectively as the sole fertilizer source at a treatment rate of $2.22 \mathrm{~kg} \cdot \mathrm{m}^{-3}$ $\left(3.742 \mathrm{lb} / \mathrm{yard}^{3}\right)$ in containerized pawpaw production. It can also be used at a lower rate of $0.81 \mathrm{~kg} \cdot \mathrm{m}^{-3}$ $\left(1.365 \mathrm{lb} / \mathrm{yard}^{3}\right)$ when supplemented with weekly applications of $500 \mathrm{mg} \cdot \mathrm{L}^{-1}(\mathrm{ppm})$ of Peters $20-20-20$ $(20 \mathrm{~N}-8.78 \mathrm{P}-16.6 \mathrm{~K})$ liquid-feed fertilizer. Bottom heating $\left[32^{\circ} \mathrm{C}\left(89.6^{\circ} \mathrm{F}\right)\right]$ of container-grown pawpaw seedlings results in greater lateral and total root dry weight than in seedlings grown at ambient temperature $\left[24^{\circ} \mathrm{C}\left(75.2^{\circ} \mathrm{F}\right)\right]$, which could increase the rate of establishment of seedlings in the field. Bottom heating of container-grown pawpaw seedlings could decrease both the time to produce a saleable plant and the cost of heating greenhouses. Growth of containerized pawpaw seedlings is enhanced by low to moderate shading with polypropylene shade fabric $(28 \%$ or $51 \%)$ outdoors and low shading $(33 \%)$ in the greenhouse, in a manner typical of that reported for other shade-preferring plants. Low to moderate shading of pawpaw seedlings grown outdoors greatly increases leaf number, total leaf area, and total plant dry weight compared to nonshaded seedlings, suggesting that commercial nurseries can improve production of containerized pawpaw seedlings using a shading regime outdoors.

$\mathrm{T}$

he pawpaw is a native North American tree fruit that has potential for use as a new high-value fruit crop or in landscapes (Layne, 1996; Pomper et al., 1999). Pawpaw fruit possess a unique, almost tropical flavor, resembling a blend of banana (Musa xparadisiaca), mango (Mangifera indica), and pineapple (Ananas comosus), and offer excellent fresh market and processing potential. Difficulties in nursery propagation have been a major factor limiting development of a commercial pawpaw fruit industry. Pawpaw seedlings develop a strong taproot with a fragile root system, which can be easily damaged upon digging (Layne, 1996); therefore, most nurseries propagate trees in containers (author, unpublished). This results in a significantly greater cost to the purchaser; however, these trees usually have strong, healthy root systems at transplanting. At Kentucky State University our long-term goal is to enhance container production of robust pawpaw seedlings that would be well-suited either for grafting or for transplanting to orchards or home landscapes.

\footnotetext{
This research was supported by U.S. Dept. of Agriculture, Cooperative State Research, Education, and Extension Service Agreement no. KYX-10-97-28P to Kentucky State University. The technical assistance of E. Reed is also gratefully acknowledged by the authors.

${ }^{1}$ Principal investigator of horticulture and curator, USDA National Clonal Germplasm Repository for Asimina species., Atwood Research Facility, Kentucky State University (KSU), Frankfort, KY 40601-2355. To whom reprint requests should be addressed.

${ }^{2}$ Associate professor of pomology and extension fruit specialist, Dept. of Horticulture, Box 340375, Clemson Univ., Clemson, SC 29634-0375.

${ }^{3}$ Research assistant, Horticulture Program, Kentucky State University.
} 


\section{Stratification and storage of pawpaw seed}

Pawpaw seed used in container production must be treated with care to optimize germination. Thompson (1974) suggested that pawpaw seed be stratified at $5^{\circ} \mathrm{C}\left(41.0^{\circ} \mathrm{F}\right)$ for eight weeks to increase germination. Finneseth et al. (1998a) found that stratification of pawpaw seed for at least 7 weeks at $5{ }^{\circ} \mathrm{C}$ increased germination from about $1 \%$ to $70 \%$.

Pawpaw has a recalcitrant seed that does not tolerate desiccation, and it only has a relatively short period of viability. It also does not tolerate subfreezing temperatures. Finneseth et al. (1998a) found that desiccation of pawpaw seed reduces viability by $50 \%$ when seed moisture content declines from 37 to $25 \%$. Storing pawpaw seed below freezing $\left(-15^{\circ} \mathrm{C}\right)$ will kill the seed (Pomper et al., 2000). The seed can be stored in moist peat moss in ziplock bags for 2 to 3 years at $5{ }^{\circ} \mathrm{C}$ and maintain a high germination percentage (Finneseth et al., 1998a).

\section{Container size}

Container size is an important consideration in the production of pawpaw seedlings. Tall containers should be used to accommodate the developing taproot of pawpaw seedlings; for example, Rootrainers (Spencer-Lemaire Industries Limited, Edmonton, Alta., Canada) that are $5.1 \times 6.35 \times 25.4 \mathrm{~cm}$ $(2 \times 2.5 \times 10$ inches $)$ with a volume of
$737.4 \mathrm{~cm}^{3}\left(45 \mathrm{inch}^{3}\right)$, or similar sized containers, have been used to successfully produce seedlings (Pomper et al., $2002 \mathrm{a}, 2002 \mathrm{~b}, 2002 \mathrm{c}$ ). Seedling vigor in containers can be quite variable if pawpaw seed is collected from trees with differing genetic backgrounds. Seedlings grown in Rootrainers should be transplanted when the seedling has produced about 10 leaves, otherwise seedlings may set a terminal bud and stop growing for that season (author, unpublished). When growing pawpaw seedlings or transplanting them, use tall containers of 3.8 to $7.6 \mathrm{~L}$ ( 1 to 2 gal) volume, such as Treepots (Stuewe and Sons, Inc., Corvallis, Ore.), to accommodate the developing taproot. In a greenhouse experiment, stratified seed was sown into Pro-Mix BX potting medium (Premier, Red Hill, Pa.) containing Osmocote 14-14-14 (Scotts Co., Marysville, Ohio) at 1.85 $\mathrm{kg} \cdot \mathrm{m}^{-3}\left(3.118 \mathrm{lb} / \mathrm{yard}^{3}\right)$ or $3.70 \mathrm{~kg} \cdot \mathrm{m}^{-3}$ $\left(6.236 \mathrm{lb} / \mathrm{yard}^{3}\right)$ in 3.8 -L containers of three different heights (short, medium, and tall) (Table 1). Plants were destructively harvested 24 weeks after sowing. Although there was great variation in seedling vigor, which was likely a result of the mixed seed source, the seedlings had the greatest root dry weight in tall 3.8-L Treepots at either rate of fertilization (Table 1). Pawpaw seedlings grown in short containers developed root spiraling (Fig. 1). The larger root system of seedlings in the taller containers should improve field establishment. With optimal greenhouse conditions and vigorous rootstock, rootstock can reach 7 to $10 \mathrm{~mm}(0.28$ to 0.39 inch $)$ in diameter in 3 months and be chip budded and scion growth forced to produce a large grafted tree $[0.9 \mathrm{~m}(3$ $\mathrm{ft}$ )] in 1 year (Layne 1996). However, less vigorous rootstock may require a 2 -year cycle, 1 year to grow graftable rootstock and a second year for the scion to grow.

\section{Potting substrate and fertilizer regime}

Through a series of greenhouse experiments, growth of pawpaw seedlings was examined in a range of potting substrates and fertilization regimes. A well-aerated potting substrate, such as Pro-Mix BX, with a high sphagnum peat moss component ( $>75 \%$ by volume), cation exchange capacity, and water holding capacity can be used effectively in pawpaw container production. Pomper et al. (2002a) found that pawpaw seedlings had the greatest plant height, leaf number, and dry weight (roots and shoots) when grown in either the potting substrate Pro-Mix BX or 1 sand: 1 sphagnum peatmoss ( $\mathrm{vol} / \mathrm{vol}$ ), as compared to 6 pine bark : 1 sand or 4 pine bark : 1 sand : 1 sphagnum peatmoss potting substrates; these seedlings were grown in Rootrainers with each substrate and fertigated with $100 \mathrm{mg} \cdot \mathrm{L}^{-1}$ Nas Peters 20-20-20 water-soluble fertilizer plus soluble trace elements once per week. Seedling root dry weight was about $30 \%$ greater and shoot dry weight about 70\% greater in Pro-Mix BX and

Table 1. Growth characteristics of pawpaw seedlings grown in a greenhouse in three different 3.8-L (1-gal) containers varying in height and at two levels of slow-release fertilizer [Osmocote 14-14-14 (14N-6.1P-11.6K)].

\begin{tabular}{|c|c|c|c|c|c|c|}
\hline Treatment $^{\mathrm{z}}$ & $\begin{array}{l}\text { Leaf } \\
\text { no. }\end{array}$ & $\begin{array}{c}\mathrm{Ht} \\
(\mathrm{cm})\end{array}$ & $\begin{array}{c}\text { Root dry } \\
\text { wt (g) }\end{array}$ & $\begin{array}{c}\text { Shoot dry } \\
\text { wt (g) }\end{array}$ & $\begin{array}{c}\text { Total dry } \\
\text { wt (g) }\end{array}$ & $\begin{array}{c}\text { Root to } \\
\text { shoot } \\
\text { ratio }\end{array}$ \\
\hline \multicolumn{7}{|l|}{ Container size } \\
\hline 1 & 24.8 & 47.4 & $2.5 \mathrm{~b}$ & 7.2 & 9.7 & $0.34 b^{y}$ \\
\hline 2 & 26.6 & 46.5 & $2.6 \mathrm{~b}$ & 7.8 & 10.4 & $0.39 \mathrm{~b}$ \\
\hline 3 & 23.9 & 46.2 & $3.4 \mathrm{a}$ & 6.3 & 9.7 & $0.56 \mathrm{a}$ \\
\hline \multicolumn{7}{|l|}{ Fertilizer level } \\
\hline 1 & 24.0 & 48.4 & 3.1 & 6.6 & 9.7 & $0.49^{\mathrm{y}}$ \\
\hline 2 & 26.2 & 45.0 & 2.6 & 7.6 & 10.2 & 0.37 \\
\hline \multicolumn{7}{|l|}{ Analysis of variance $P$} \\
\hline Block & 0.76 & 0.43 & $0.03^{*}$ & 0.75 & 0.06 & $0.01^{*}$ \\
\hline Container size & 0.49 & 0.94 & $0.02^{*}$ & 0.20 & 0.74 & $0.01^{*}$ \\
\hline Fertilizer & 0.24 & 0.24 & 0.07 & 0.12 & 0.53 & $0.01^{*}$ \\
\hline Container size $\times$ fertilizer & 0.24 & 0.26 & 0.87 & 0.72 & 0.73 & 0.50 \\
\hline
\end{tabular}




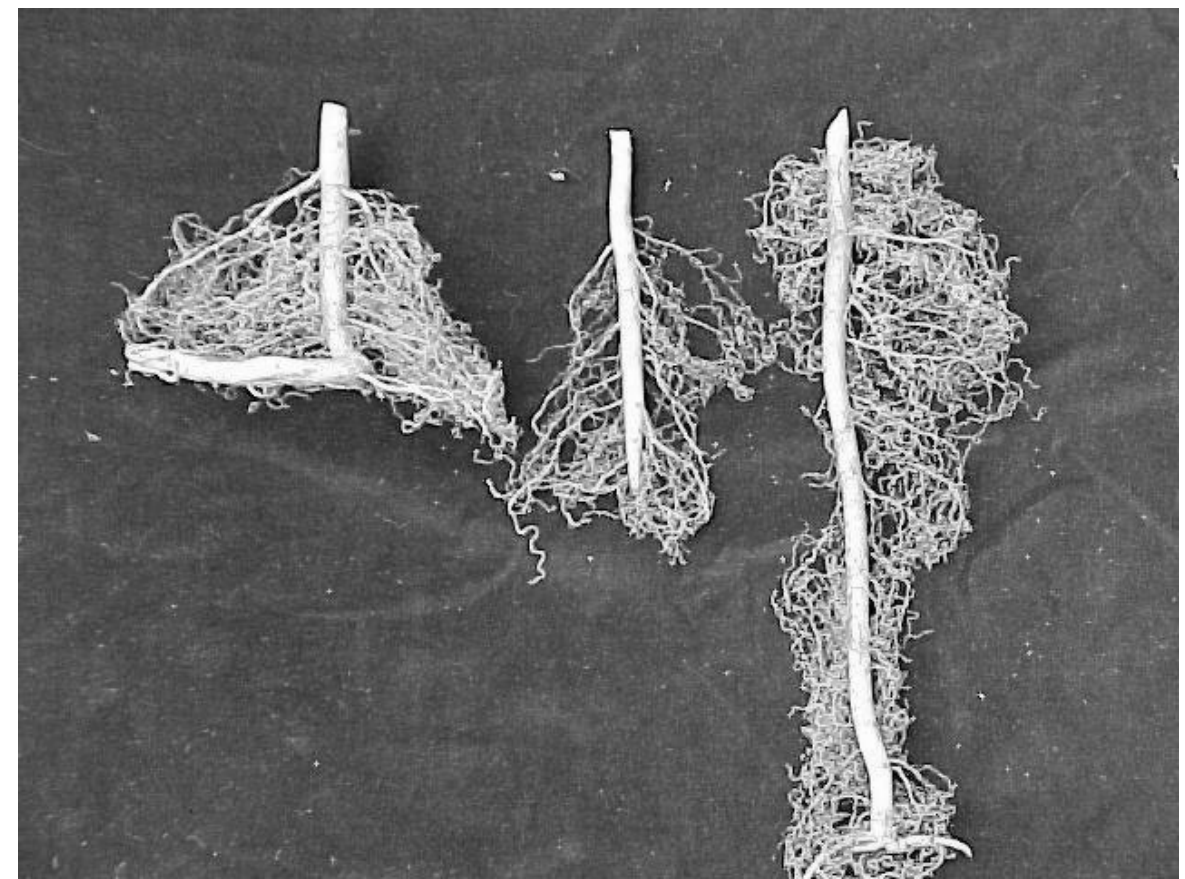

Fig. 1. Root growth characteristics of pawpaw seedlings grown in a greenhouse in three different one gallon containers varying in height and with the slow-release fertilizer Osmocote $14-14-14(14 \mathrm{~N}-6.1 \mathrm{P}-11.6 \mathrm{~K})$ at a rate of $1.85 \mathrm{~kg} \cdot \mathrm{m}^{-3}$ $\left(3.118 \mathrm{lb} / \mathrm{yard}^{3}\right)$. From left to right, root systems were from seedlings grown in containers that were $12.7 \mathrm{~cm}$ (5 inches), $17.8 \mathrm{~cm}$ (7 inches), and $35.6 \mathrm{~cm}$ (14 inches) in height, respectively. Note the spiraling taproot for the seedling grown in the short container.

1 sand: 1 sphagnum peatmoss substrates than in 6 pine bark : 1 sand or 4 pine bark : 1 sand : 1 sphagnum peatmoss potting substrates.

Fertilization requirements for container grown pawpaw seedlings have recently been determined (Pomper et al., 2002 b, 2002c). Slow-release fertilizers can be used to efficiently meet most of the nutritional needs of containergrown nursery crops. Osmocote is a popular encapsulated, slow-release fertilizer that provides a relatively constant supply of nutrients for plant absorption over a fixed time frame. Because fertilizers such as Osmocote release nutrients slowly, they eliminate the need for labor-intensive liquid fertilization that may lead to excessive nutrient leaching and contamination of ground water (Nelson, 1998). Osmocote, alone or in combination with water-soluble fertilizer, was used to successfully produce pawpaw seedlings. Osmocote 14-14-14 incorporated into Pro-Mix BX potting substrate can be used effectively as the sole fertilizer source at a treatment rate of $2.22 \mathrm{~kg} \cdot \mathrm{m}^{-3}$ in containerized production (Pomper et al., 2002c). It can also be used at the lower rate of 0.81 $\mathrm{kg} \cdot \mathrm{m}^{-3}$ when supplemented with weekly applications of $500 \mathrm{mg} \cdot \mathrm{L}^{-1}$ of Peters
20-20-20 plus micronutrients liquidfeed fertilizer. If pawpaw seedlings are grown for longer than 4 months with Osmocote 14-14-14 as the sole fertilizer source in the potting substrate Pro-Mix BX, it is possible that seedlings will display micronutrient deficiency symptoms (author, unpublished). Thus, if pawpaw seedlings are to be grown in containers with Pro-Mix BX, or similar peat based medium, for longer than four months, the plants should receive a one-time application of soluble trace element mix (S.T.E.M.; Scotts Co., Marysville, Ohio) at a rate of $0.6 \mathrm{~g} \cdot \mathrm{L}^{-1}(8 \mathrm{oz} / 100 \mathrm{gal})$ about 3 months after sowing. Pawpaw seedlings grown for longer than 4 months in the potting substrate Pro-Mix BX may also develop calcium deficiency symptoms. One or more applications of calcium nitrate at a rate of $500 \mathrm{mg} \cdot \mathrm{L}^{-1}$ should also be provided to pawpaw seedlings at 3 months after sowing to avoid the development of calcium deficiency symptoms in plants.

Finneseth et al. (1998b) reported that early pawpaw seedling development can be divided into four distinct stages including radicle protrusion, hypocotyl emergence, epicotyl elongation, and seedcoat abscission. At the time of epicotyl elongation, which can be more than $50 \mathrm{~d}$ after sowing, the radicle and developing root system can comprise up to $81 \%$ of the seedling biomass. When Osmocote was incorporated in the potting substrate at a rate of $2.22 \mathrm{~kg} \cdot \mathrm{m}^{-3}$ as the sole fertilizer source, seedling emergence and growth were hastened compared to control plants (Pomper et al., 2002c). This was likely the result of the acceleration of the four stages of seedling development due to Osmocote being incorporated in the potting substrate. High rates of Osmocote 14-14-14 [17.7 $\mathrm{kg} \cdot \mathrm{m}^{-3}(29.83$ $\left.\left.\mathrm{lb} / \mathrm{yard}^{3}\right)\right]$ incorporated into Pro-Mix BX potting substrate can delay seedling development when compared to nonfertilized control plants (Pomper et al., 2002c), possibly due to seedlings being sensitive to high soluble salt levels.

Pawpaw seedlings will grow well in a medium that has a relatively low pH. Mandujano and Fulbright (1998) reported that pawpaw seedlings in containers grew well and appeared very healthy in the $\mathrm{pH}$ range of 5.0 to 5.6, but at $\mathrm{pH} 5.7$ to 6.0 they observed some leaf curling and tip burn. A pH of 5.6 was determined for Pro-Mix BX before sowing pawpaw seeds (Pomper 2002b).

\section{Bottom heating of seedlings}

Elevated root zone temperatures have been reported to significantly increase nutrient uptake and dry weight production in plants such as passionfruit (Passiflora edulis) (Menzel et al., 1994), flowering and stem length for hydroponically grown roses (Rosa xhybrida) (Moss, 1984), and nitrogen accumulation by apple trees (Malus $\times$ sylvestris var. domestica) (Toselli et al., 1999). Bottom heating $\left(32{ }^{\circ} \mathrm{C}\right)$ of containers hastens pawpaw seedling emergence from Pro-Mix BX by $9 \mathrm{~d}$ compared to ambient root-zone conditions $\left(24^{\circ} \mathrm{C}\right)$ (Pomper et al., 2002a). Seedlings subjected to bottom heat show increased leaf number $(30 \%)$, plant height $(32 \%)$, whole plant leaf area $(94 \%)$, shoot dry weight (104\%), root dry weight $(50 \%)$, lateral root dry weight (125\%), and total plant dry weight $(87 \%)$. Bottom-heated seedlings also have a lower root:shoot ratio $(25 \%)$ than plants grown at ambient temperature. Bottom heating of container grown pawpaw seedlings could decrease both the time to produce a saleable plant and the cost of heating greenhouses. Bottom heating also pro- 
duces greater lateral and total root dry weight than in pawpaw seedlings grown at ambient temperature; this could result in a higher rate of establishment of bottom heated seedlings in the field.

\section{Incident light level}

Plant biomass production and partitioning can be significantly influenced by incident irradiance upon the plant (Buisson and Lee, 1993; Givinish, 1988; Rajapakse et al., 1999). Shadepreferring plants [e.g., rhododendron (Rhododendron), english boxwood (Buxus sempervirens), and chinese holly (Ilex cornuta) showed increased root and shoot weight with moderate shading (Whitcomb, 1988). With the shade-preferring plant belgian evergreen (Dracaena sanderana), moderate shading decreased the root:shoot ratio and increases plant biomass and leaf area (Vladimirova et al., 1997).

Pawpaw seedlings grown outdoors have been reported to be sensitive to high irradiance upon emergence from the soil, and benefit from partial shading during the first year of development (Gould, 1939; Peterson, 1991). Seedlings produced in greenhouses do not show sensitivity to high light levels, suggesting that seedlings grown outdoors may be sensitive to ultraviolet (UV) radiation (Peterson, 1991).

Pomper et al. (2002a) found that growth of containerized pawpaw seedlings was positively influenced by low to moderate shading with polypropylene shade fabric $(28 \%$ or $51 \%$, respectively) outdoors and low shading $(33 \%)$ in the greenhouse, in a manner typical of that reported for other shade-preferring plants. Low to moderate shading of pawpaw seedlings grown outdoors greatly increased leaf number, total leaf area, and total plant dry weight compared to nonshaded seedlings, indicating that commercial nurseries can improve production of containerized pawpaw seedlings by using a shading regime outdoors. If plants are produced on a gravel container pad, higher levels of shading ( $>55 \%)$ that would also reduce air temperatures could be beneficial. Shading of fieldplanted pawpaw trees has been suggested to assist in the establishment of young trees (Layne 1996). Trees that are taller than $0.46 \mathrm{~m}(1.5 \mathrm{ft}) \mathrm{do}$ not require shading the first year, but trees should be provided irrigation to enhance establishment (author, unpublished).

\section{Copper compounds in containers}

A serious problem with transplanting container-grown trees is poor root development (i.e., circled, matted, and kinked roots), which is associated with increased tree mortality (Nichols and Alm, 1983). A water based latex paint containing cuprichydroxide $\left[\mathrm{Cu}(\mathrm{OH})_{2}\right]$ has been used in commercial nurseries to treat the interior surface of containers and successfully reduce root spiraling in several tree species (Ruter, 1994). Root elongation is inhibited when root tips encounter copper compounds in paint applied to container walls, causing lateral branching from older root regions more distant from the root tip and the formation of a more fibrous root system and a lower root:shoot ratio (Arnold and Struve, 1989, 1993; Arnold and Young, 1991). Pomper et al. (2002a) reported that application of $\mathrm{Cu}(\mathrm{OH})_{2}$ to the interior of Rootrainers did not promote development of a more fibrous root system in pawpaw seedlings, based on failure of copper compound to increase lateral root dry weight production (Pomper 2002a). Seedlings also showed yellowing of leaves and reduced chlorophyll levels by the end of the experiment in shaded plants, suggesting that the plants were suffering from copper toxicity. The use of larger containers and lower concentrations of $\mathrm{Cu}(\mathrm{OH})$, compared to those used by Pomper (2002a) might reduce plant copper toxicity problems and stimulate lateral branching of seedling root systems.

In conclusion, recent studies have allowed the development of recommendations (e.g., potting substrate type, fertilizer regime, the use of tall containers to accommodate the seedling's strong tap root, bottom heating, and shading regime) toward successful container production of pawpaw. However, further improvements in cultural methods for container production of robust pawpaw seedlings for grafting, transplanting to orchards, or home landscapes would be desirable.

\section{Literature cited}

Arnold, M.A. and D.K. Struve. 1989. Growing green ash and red oak in $\mathrm{CuCO}_{3}$-treated containers increase root regeneration and shoot growth following transplant. J. Amer. Soc. Hort. Sci. 114:402-406.

Arnold, M.A. and D.K. Struve. 1993.
Root distribution and mineral uptake of coarse-rooted trees grown in cupric hydroxide-treated containers. HortScience 28:988-992.

Arnold, M.A. and E. Young. 1991. $\mathrm{CuCO}_{3}$ painted containers and root pruning affect apple and green ash root growth and cytokinin levels. HortScience 26:242-244.

Buisson, D. and D.W. Lee. 1993. The developmental response of papaya leaves to simulated canopy shade. Amer. J. Bot. 80:947-952.

Finneseth, C.L.H., D.R. Layne, and R.L. Geneve. 1998a. Requirements for seed germination in North American pawpaw [Asimina triloba (L.) Dunal.]. Seed Sci. Technol. 26:471-480.

Finneseth, C.L.H., D.R. Layne, and R.L. Geneve. 1998b. Morphological development of pawpaw [ Asimina triloba (L.) Dunal.] during seed germination and seedling emergence. HortScience 33:802-805.

Givinish, T.J. 1988. Adaptation to sun and shade: A whole-plant perspective. Austral. J. Plant. Physiol. 15:63-92.

Gould, H. 1939. The native pawpaw. USDA Lflt. 179.

Layne, D.R. 1996. The pawpaw [Asimina triloba (L.) Dunal.]: A new fruit crop for Kentucky and the United States. HortScience 31:777-784.

Mandujano, M. and D.W. Fulbright. 1998 Meristem dieback of greenhouse-grown pawpaw is associated with soil $\mathrm{pH}$. Annu. Rpt. N. Nut Growers Assn. 89:103-107.

Menzel, D.M., D.W. Turner, V.J. Doogan, and D.R. Simpson. 1994. Root shoot interactions in passionfruit (Passiflora sp.) under the influence of changing root volumes and soil temperatures. J. Hort. Sci. 69:552-564.

Moss, G.I. 1984. The effects of root-zone warming on the yield and quality of roses grown in a hydroponic system. J. Hort. Sci. 59:549-558.

Nelson, P.V. 1998. Greenhouse operation and management. Prentice-Hall, Upper Saddle River, N.J.

Nichols, T.J. and A.A. Alm. 1983. Root development of container-reared, nurserygrown, and naturally regenerated pine seedlings. Can. J. For. Res. 13:239-245.

Peterson, R.N. 1991. Pawpaw (Asimina) In: J.N. Moore and J.R. Ballington (eds.). Genetic resources of temperate fruit and nut trees. Acta Hort. 290:567-600.

Pomper, K.W., D.R. Layne, and R.N. Peterson. 1999. The pawpaw regional variety trial, p. 353-357. In: J. Janick (ed.). Perspectives on new crops and new uses. ASHS Press, Alex., Va. 
Pomper, K.W., S.C. Jones, and L. Barnes. 2000. The influence of low temperature storage on the germination rate of pawpaw [Asimina triloba (L.) Dunal.] seed. Annu. Rpt. N. Nut Growers Assn. 91:20-27.

Pomper, K.W., D.R. Layne, and S.C. Jones. 2002a. Incident irradiance and cupric hydroxide container treatment effects on early growth and development of container-grown pawpaw seedlings. J. Amer. Soc. Hort. Sci. 127:13-19.

Pomper, K.W., D.R. Layne, S.C. Jones, and M.G. Kwantes. 2002b. Growth enhancement of container-grown pawpaw seedlings as influenced by media type, root-zone temperature, and fertilization regime. HortScience 37:329-333.
Pomper, K.W., D.R. Layne, E.B. Reed. 2002 c. Determination of the optimal rate of slow-release fertilizer for enhanced growth of pawpaw seedlings in containers. HortTechnology 13:397-401.

Rajapakse, N.C., R.E. Young, M.J. McMahon, and R. Oi. 1999. Plant height control by photoselective filters: Current status and future prospects. HortTechnology 9:618-624.

Ruter, J.M. 1994. Growth responses of four vigorous-rooted tree species in cupric hydroxide-treated containers. HortScience 29:1089.

Thompson, P.H. 1974. The paw paw -Brought up to date. Calif. Rare Fruit Growers Yrbk. 6:138-180.
Toselli, M., J.A. Flore, B. Marangoni, and A. Masia. 1999. Effects of root-zone temperature on nitrogen accumulation by non-bearing apple trees. J. Hort. Sci. Biotechnol. 74:118-124.

Vladimirova, S.V., D.B. McConnell, and M.E. Kane. 1997. Morphological plasticity of Dracaena sanderana 'Ribbon' in response to four light intensities. HortScience 32: 1049-1052.

Whitcomb, C.E. 1988. Growing media, p. 464-480. In: C.E. Whitcomb (ed.). Plant production in containers. Lacebark Publ., Cambridge, Mass. 